\title{
The growth patterns, hemoglobin pretransfusion, serum ferritin and bone age in thalassemia major patients
}

\author{
Made Arimbawa*, Ketut Ariawati \\ From 7th APPES Biennial Scientific Meeting \\ Nusa Dua, Bali. 14-17 November 2012
}

Despite frequent blood transfusions combined with chelation therapy lead to an improved rate of survival, endocrine disorders related to secondary hemosiderosis such as short stature, delayed puberty and hypogonadism are major problems in adolescent children with thalassemia major. The aim of this study was to know the description of height, growth velocity, bone age, hemoglobin pretranfusion level and serum ferritin in thalassemic patients.

The retrospective study of children hospitalized in Pediatrics ward Sanglah Hospital Denpasar from December 2010-February 2011.

Fifteen subjects were diagnosed as thalassemia major, aged between 1.91 years - 13.5 years; 7 boys and 8 girls. Two children aged less than 3 years and 7 children had entered puberty. All patients had to undergo iron chelation therapy deferioksamin with inadequate quality. Short stature was found in 4 children (26\%), all with growth velocity of $<5 \mathrm{~cm} /$ year. Clinically 1 person categorized as delayed puberty. Mean hemoglobin pretranfusion levels can be maintained \&\#8805; $8 \mathrm{mg} / \mathrm{dl}$ (10), the remainder (5) has an average hemoglobin below $8 \mathrm{mg} / \mathrm{dl}$. Four children with serum ferritin over $3000 \mathrm{ng} / \mathrm{ml}$, all with short stature. In the radiological evaluation (bone age) 5 children have delayed bone age.

Our study suggests that thalassemic patients, short stature is found in $26 \%$ cases and all of them have entered the age of puberty. All patients with short stature has serum ferritin levels $>3000 \mathrm{ng} / \mathrm{ml}$.

Published: 3 October 2013

Departement of Pediatrics, Medical Faculty, Udayana University/Sanglah Hospital, Denpasar-Bali, Indonesia
doi:10.1186/1687-9856-2013-S1-P41

Cite this article as: Arimbawa and Ariawati: The growth patterns, hemoglobin pretransfusion, serum ferritin and bone age in thalassemia major patients. International Journal of Pediatric Endocrinology 2013 2013(Suppl 1):P41.
Submit your next manuscript to BioMed Central and take full advantage of:

- Convenient online submission

- Thorough peer review

- No space constraints or color figure charges

- Immediate publication on acceptance

- Inclusion in PubMed, CAS, Scopus and Google Scholar

- Research which is freely available for redistribution
C Biomed Central

\section{Biomed Central}

